scien do Zagreb International Review of Economics \& Business, Vol. 21, Special Conference Issue, pp. 15-30, 2018 (C) 2018 Faculty of Economics and Business, University of Zagreb and De Gruyter Open All rights reserved. Printed in Croatia ISSN 1331-5609; UDC: $33+65$

DOI: 10.2478 /zireb-2018-0021

CONFERENCE PAPER

\title{
The Impact of Gender-Specific Human Capital on Economic Growth: An Empirical Investigation for Turkey
}

\author{
Hacer Simay Karaalp-Orhan*
}

\begin{abstract}
In this study, how the human capital disaggregated by gender and physical capital affects economic growth in Turkey is examined for the period of 1971-2015. By using an arithmetic average of health and education indicators as a proxy of human capital formation, an attempt was made to examine the relationship between the human capital and economic growth under the scope of gender inequality. In this context, an ARDL-bounds testing approach and the unrestricted error-correction model were used to investigate the co-integration in the long-run and short run. Further, the causality test was also conducted to identify the direction of the causality between the variables. The main finding indicates that male human capital has been the central variable affected by both economic growth and physical capital. On one hand, a significant positive relationship was found between the economic growth and physical capital and male human capital in the long-run, while on the other hand, the female human capital was associated negatively to the economic growth. There is no evidence of causality that links the female human capital to other variables. This result suggests that women are not well utilized in the Turkish economy and the country suffers from untapped potential of women.
\end{abstract}

Keywords: ARDL; economic growth; human capital; gender; Turkey

JEL Classification: F43, C22, J24

\section{Introduction}

The most debated subject in the economics literature is the determinants of economic growth and the effects of factor accumulation (physical and human capital) or productivity. While Chow (1993), Hu and Khan (1997), and others supported the view that productivity growth causes economic growth, Krugman (1994) suggested an

\footnotetext{
${ }^{*}$ Hacer Simay Karaalp-Orhan is at Pamukkale University, Faculty of Economics and Administrative Sciences, Kınıklı Campus, Denizli, Turkey.
} 
effect of factor accumulation on economic growth. As a third strand, the neoclassical growth models of Solow (1956) and the endogenous growth models of Romer (1990) and Lucas (1988) focus on the effect of human capital on economic growth. Human capital theories, advocated by Schultz (1961), Becker (1964), Lucas (1988) and Romer (1990), state that human capital investment promotes higher labor productivity, individual earnings, and national economic growth. In some empirical studies, Barro (1991) and Barro and Lee (1993) found evidence that human capital fosters long-run growth rates of a country. Lucas (1988) postulated the existent of a relationship between physical and human capitals. If there is underinvestment in human capital, then there will be under or limited utilization of physical capital (Lucas, 1988). Becker (2007) considered the complementary effect of education and health on human capital. The investments in human capital are made to improve health, education, and skills of the labor force, which altogether enhance the technological progress that reduces poverty and boosts economic growth. Schultz (2003) considered that sustained growth in total factor productivity and reduced poverty are closely associated with improvements in a population's child nutrition, adult health, and schooling, particularly in low-income countries. In this context, almost every developing country is suffering from two major issues: the first one is how to attain and sustain economic growth and the second is how to deploy women for the economic growth and decrease inequalities. The poor involvement of women in the economy and insufficient investments on female human capital are considered as obstacles to the economic growth of developing countries. In developing countries, women are not completely utilized and highly unvalued. They also face discrimination in many areas of life. The integration of women into the economy and gender equality should be vital in all aspects because it can increase the overall productivity and economic growth, reduce poverty, enhance social well-being, and help ensure sustainable development. Turkey is also one of the countries subject to gender inequality and women suffer from unequal opportunities in health, education, and economic life.

One of the salient characteristics of Turkish labor market is the untapped potential of women in the Turkish economy and the low participation rate of women in the economy. While the employment and labor force participation rate (LFPR) of Turkey is exceptionally low as per international standards, being $28 \%$ and $32.5 \%$, respectively, the unemployment rate is $13.4 \%$ in 2016 (TURKSTAT, 2018). While the educational attainment in Turkey has increased over the period and the educational opportunities have expanded significantly, the average educational level for employment is relatively low in Turkey, as the highest share in the total employment is below the level of high school education (Karaalp-Orhan, 2017 (a)). Women in Turkey face a number of difficulties that prevent them from playing any role in the economy. In addition to social-cultural and economic constraints that hinder labor force participation of women, ongoing structural and sectoral transformations of Turkish economy also decrease the participation of women in the labor market. Women also face dis- 
crimination for the access to education opportunities and thus do not get high wages, formal and better jobs, and mostly are subjected to gender-based wage discrimination. On the other hand, under the influence of the patriarchal point of view, Turkish women also face gender-based occupational segregation. In Turkey, the majority of women (55\%) employed in the service sector, include $18 \%$ in the education sector, $17 \%$ in health sectors and $29 \%$ are employed in the agricultural sector. It was reported for 2016 that $23 \%$ of women in the agricultural sector are working as unpaid family workers (TURKSTAT, 2018). The fact that the women with children and a low education level face more socio-cultural obstacles emphasizes that women's domestic roles restrict their participation in the labor force after marriage (Karaalp-Orhan, 2017 (b)).

In this context, the main objective of this study was to measure the relationship between economic growth and factor accumulation (physical capital and human capital in terms of gender) in Turkey by using the autoregressive distributed lag (ARDL) approach for cointegration analysis and Toda-Yamamoto's (1995) causality tests. This study differs from the earlier ones in two ways. First, both health and education indicators were used as proxies for human capital and then the effect of gender differentials on human capital was considered in the econometric model for Turkey. In this context, this study attempts to analyze the human capital formation considering an arithmetic average of education and health indicators and to trace out the relationship between the human capital and economic growth under the scope of gender inequality. In this context, this paper is structured as follows. Section 2 explains the theoretical background; Section 3 describes the data and methodology; Section 4 presents the empirical results and, finally, Section 5 concludes.

\section{Theoretical Background}

In the field of macroeconomics, both neoclassical growth models of Solow (1956) and endogenous growth models of Romer (1990) and Lucas (1988) argue that human capital accumulation has a positive impact on economic growth. The human capital theories, backed by Schultz (1961), Becker (1964), Lucas (1988) and Romer (1990), affirm that human capital investment, by means of education, enables higher individual earnings and, labor productivity that ultimately translate into national economic growth. Accumulating physical capital by utilizing human capital is a more useful and productive approach to the economic growth of countries because the effective use of physical capital is possible only with a skilled and educated workforce. The increase in human capital by education, training, health, and R\&D translates into the growth of physical productivity and the whole economy. Thus considering the importance of human capital, its measurement in terms of analyzing its effect on the economy and then suggesting and implementing policies regarding human resources are 
crucial (Dae-Bong, 2009). Several empirical studies have used various conventional proxies to measure human capital as dimensions of education and training, such as the number of new school graduates (Wang and Yao, 2003), gross/net educational enrollment ratios (Barro and Lee, 1993; Asteriou and Agiomirgianakis, 2001), the average years of schooling (measured by the average years of schooling for the population aged 15 and over) (Barro and Lee, 2013; Lee, 2005), the share of people having higher education to the population of people with ages over 15 (Chuang, 2000), literacy (Khan et al.,1991), and public educational expenditures (Jung and Thorbecke, 2003). However, there are very few discussions on health as human capital. The education and training are not the only sources of human capital but along with them, health is also an important component of human capital. The all together boost the productivity of labor and, economic growth and reduce poverty. Thirlwall (2006) stated that investments in human capital comprise all investments made in order to improve health, education, and skills of the labor force. Becker (2007) considered that health and schooling behave as complements. The probability of surviving at later ages increases the returns from investments in education because educational costs incur at earlier ages and returns at later ages. He stated that higher education is complementary with longer life expectancy. Highly educated people take better care of their health with a given spending on medical care by visiting better doctors, taking prescribed medicines regularly, eating nutritious diets, and hence they have higher earnings, and save more. They follow healthy habits, and tend to have better survivorship rates at older ages too. Therefore, incentives of investing in health capital are worthwhile, just as they are in education and job training investments. The new approach of human capital measurement led to the conception of the Human Development Index (HDI) within the framework of health, knowledge, and standard living with many sub-variables such as life expectancy at birth, adult literacy rate, gross enrollment ratio, and GDP per capita.

On the other hand, women, who constitute half of the human capital, are one of its most underutilized and undervalued resources. The better use of the female population, increasing the FLFPR, and decreasing the economic inequalities between men and women can boost the economic growth, reduction of poverty and income inequality, better governance, business performance and innovation, social well-being, and sustainable development in all countries. Gender inequality is more prominent in the developing countries and is considered as one of the obstacles to their economic growth (Morrison et al., 2007). In the literature, there are many empirical studies favoring a strong and positive relationship between human capital and economic growth. However, the female and male human capital stock may exert different effects on economic growth. The relative importance of human capital accumulation, disaggregated by gender, has been given limited attention. The results of the relationship between economic growth and gender-based human capital are ambiguous. Barro and Lee $(1994,1996)$ investigated gender separate human capital and found 
its negative effect on economic growth and extended the measure of human capital by including both education and life expectancy as a proxy of human capital. Barro (2001) suggests that highly educated women are not well utilized in the labor markets of many countries. However, Knowles et al. (2002) find a positive effect of female education on output using cross-country data. Kaur and Letic (2012) concluded that female education affects economic growth positively, through human capital and fertility rate in for India and Niger. Cooray et al. (2014) found the female human capital stock influencing economic growth negatively when different levels of openness are considered for South Asia. Yet, male human capital has a positive impact for the same. However, Önder and Önder (2012) analyzed the relationship between different education levels of women as a proxy for human capital and found a long-run relationship and bidirectional causality between the different education levels of women and the economic growth of Turkey. The findings of provincial study of Tansel and Güngör (2003) indicate that female education positively and significantly affects the steady-state level of labor productivity, while the effect of male education is in general either positive or insignificant in Turkey. Öztunç et al. (2015) found that tertiary school enrolment of women has a negative effect on economic growth in Asia Pacific countries. Khan (2016) observed a positive and significant relationship between the female human capital and economic growth of Pakistan over a time period of 1972-2012. By taking education and health as a proxy for human capital, Sehravat and Giri (2017) found a positive and significant effect of female human capital on economic growth; they found a positive but insignificant relationship between physical and male human capital and economic growth of India. A long-run causal relationship of female human capital, male human capital, and physical capital to economic growth was found.

\section{Empirical Model and Data}

The core model that is employed to investigate the effects of factor accumulation to economic growth is the Cobb-Douglas production function with constant returns to scale. Using annual time series data for the period of 1971 to 2015, the empirical specification of the following economic growth form is proposed:

$$
Y_{t}=\gamma_{0}+\gamma_{1} P H Y_{t}+\gamma_{2} M H U M_{t}+\gamma_{3} F H U M+\varepsilon_{t}
$$

where Yt is economic growth, PHYt is the physical capital, MHUMt is the male human capital, FHUMt is the female human capital, and $\varepsilon t$ is the regression error term that captures all other effects. The parameters $\gamma_{1}, \gamma_{2}$, and $\gamma_{3}$ represent long-run elasticity of economic growth with respect to PHY, MHUM, and FHUM, respectively. All variables are expressed in logarithmic form. Real GDP per capita measured for 2010 in US dollars is used as a proxy for economic growth; and gross fixed capital 
formation (\% of GDP) is used as a proxy for physical capital. In order to analyze the effect of gender differences, the growth model is created with segregated human capital (male and female) as explanatory variables. Education and health are the two important components of human capital. For this reason, given that health and education have an equal effect on human capital, an arithmetic average of education and health indicators was used as a proxy of human capital formation. In this context, by using the tertiary school enrollment rates as a proxy for education and life expectancy at birth as a proxy for health, an attempt was made to unravel the relationship between the human capital and economic growth under the purview of gender inequality. Life expectancy at birth is frequently used to proxy for the stock of health capital. A number of researchers such as Barro and Lee (1994), Knowles and Owen (1995) and Knowles et al. (2002) used life expectancy as an indicator of health status. All data were collected from World Bank WDI (World Development Indicators) (World Bank, 2018). The annual sample period of this study was from 1971 to 2015.

\section{Methodology}

Equation (1) was estimated using the Auto Regressive Distributed Lag (ARDL) cointegration procedure developed by Pesaran, Shin, and Smith (2001). As a first step, in order to test the stationarity of variables and the integration and the possible cointegration among the variables, the augmented Dickey-Fuller (ADF) test (Dickey and Fuller, 1981) and an alternative Phillips-Perron (PP) unit-root test (Phillips and Perron, 1988) are employed. Following the stationarity tests, the bounds test for co-integration within ARDL modeling approach was adopted to determine whether a long-run relationship exists between economic growth and human capital and physical capital in Turkey. This model has several advantages as compared to the standard multivariate cointegration test such as Johansen and Juselius (1990). Since the bounds testing approach can be applied irrespective of the order of integration of the variables, the regressors can be I(1), I(0) or mutually cointegrated. Therefore, this method eliminates the pretesting problems associated with the standard cointegration test such as the classification of variables into I(0) and I(1). First of all, ARDL cointegration procedure examine the existence of the long-run relationship between the variables in the model. After the cointegration exists, the second step is to estimate the long-run and short-run coefficients using associated ARDL and error correction models (ECMs). In this context, the following ECM (error correction model) was estimated:

$$
\begin{gathered}
\Delta G D P_{t}=\alpha_{0}+\sum_{i=1}^{p-1} \alpha_{1} \Delta G D P_{t-i}+\sum_{i=1}^{p-1} \alpha_{2} \Delta P H Y_{t-i}+\sum_{i=1}^{p-1} \alpha_{3} \Delta M H U M_{t-i}+\sum_{i=1}^{p-1} \alpha_{4} \Delta F H U M_{t-i} \\
+\alpha_{5} G D P_{t-1}+\alpha_{6} P H Y_{t-1}+\alpha_{7} M H U M_{t-1}+\alpha_{8} F H U M_{t-1}+\mu_{t}
\end{gathered}
$$


Equation (2) can be further transformed to accommodate the one period lagged error correction term (ECTt-1) as in equation (3).

$$
\begin{aligned}
\Delta G D P_{t}=\alpha_{0}+ & \sum_{i=1}^{p-1} \alpha_{1} \Delta G D P_{t-i}+\sum_{i=1}^{p-1} \alpha_{2} \Delta P H Y_{t-i}+\sum_{i=1}^{p-1} \alpha_{3} \Delta M H U M_{t-i}+\sum_{i=1}^{p-1} \alpha_{4} \Delta F H U M_{t-i} \\
& +\lambda E C T_{t-1}+\mu_{t}
\end{aligned}
$$

where $\Delta$ is first difference operator and $\mu \mathrm{t}$ is the serially independent random error with zero mean and finite covariance matrix, and the deterministic term, constant, is denoted by $\alpha 0$. In Equation (3), the parameter $\lambda$ represents the long-run relationship and $\alpha_{1}, \alpha_{2}, \alpha_{3}$ and $\alpha_{4}$ represent short-run dynamics of the model. In order to examine the long-run relationship between the dependent variable and its determinants, an F-test procedure is followed to estimate the combined significance of the coefficients of the lagged levels of the variables. While the null hypothesis is H0: $\alpha_{5}=\alpha_{6}=\alpha_{7}=\alpha_{8}=0$ (no cointegration) and the alternative hypothesis is $\mathrm{H} 1: \alpha_{5} \neq \alpha_{6} \neq \alpha_{7} \neq \alpha_{7} \neq 0$ (cointegration). If the null hypothesis is rejected, it indicates the existence of a long-run relationship or cointegration. Pesaran et al. (2001) provided a set of asymptotic critical values where the critical bounds can be applied irrespective of the order of integration of the regressors. The critical values are composed of two sets: lower bounds I(0) and upper bounds I(1). The first set gives the lower bound, applicable when all regressors are $\mathrm{I}(0)$. The second one gives the upper bound, applicable when all regressors are I(1). If the calculated F-statistic exceeds the upper bound, the null hypothesis of no relationship between dependent variable and independent variables can be rejected. Conversely, if the F-statistic falls below the lower bound, the null hypothesis of no long-run relationship cannot be rejected. However, if the F-statistic falls within the critical bounds, the result of cointegration will be inconclusive. If cointegration is established, then the long-run coefficients can be estimated by the ARDL model using the OLS method. Since the ARDL model assumes no serial correlation in errors, an appropriate lag level (m) should be chosen according to a model based on information criteria such as AIC (Akaike Information Criterion), SC (Schwarz Information Criterion), HQ (Hannan-Quinn Information Criterion), FPE (Final Prediction Error) and LR (Sequential Modified LR Test Statistic).Then the short-run dynamics are estimated through the error correction model.

As the last step, the Granger causality test is applied to examine the causal linkages between economic growth, physical capital, male and female human capital. The notion of the Granger causality (Granger, 1969; Engle and Granger, 1987) is one of the most commonly and extensively used methods for evaluating the existence and direction of linkages among time series variables within vector autoregressive (VAR) models in economics literature (Pitarakis and Tridimas, 2003:362). According to Sims et al. (1990), the asymptotic distribution theory cannot be applied for testing causality of integrated variables in the level from using the VAR model even if the variables are cointegrated (Clark and Mirza (2006) and Wolde-Rufael (2007)). In this 
context, Toda and Yamamoto (1995) proposed an alternative approach that can be applied in the level VARs irrespective of whether the variables are integrated, cointegrated, or not. Toda and Yamamoto (1995), on the basis of augmented VAR(k) modeling, introduced a modified Wald test statistic that asymptotically has a chi-square $\left(\chi^{2}\right)$ distribution irrespective of the order of integration or cointegration properties of the variables in the model. The test has two steps: Firstly, in order to apply Toda and Yamamoto's approach (1995), it is essential to determine the true lag length $(\mathrm{k})$ and the maximum order of integration (dmax) of the series under consideration. The modified Wald test statistic is valid regardless of whether a series is $\mathrm{I}(0), \mathrm{I}(1)$ or $\mathrm{I}(2)$ non-cointegrated or cointegrated of an arbitrary order. The lag length, $\mathrm{k}$, is obtained in the process of the VAR in levels among the variables in the system by using different lag length criterion. Then the unit root testing procedure can be used to identify the order of integration $(\mathrm{dmax})$. As the second step, the modified Wald test procedure is used to test the VAR (k) models for causality. The VAR (k) models are estimated by Ordinary Least Squares (OLS) estimation technique. Unlike the Granger causality test, Toda and Yamamoto's approach (1995) fits a standard vector auto-regression on the levels of the variables, not on the first difference of the variables. Therefore, to undertake Toda and Yamamoto's version (1995) of the Granger non-causality test, the following VAR system is presented:

$$
\begin{aligned}
& \ln Y_{t}=\alpha_{0}+\sum_{i=1}^{k} \alpha_{1 i} \ln Y_{t-i}+\sum_{j=1}^{k+d \max } v_{1 j} \ln Y_{t-j}+\sum_{i=1}^{k} \phi_{1 i} \ln X_{t-i}+\sum_{j=1}^{k+d \max } \psi_{1 j} \ln X_{t-j}+\lambda_{1 t} \\
& \ln X_{t}=\beta_{0}+\sum_{i=1}^{k} \delta_{1 i} \ln Y_{t-i}+\sum_{j=1}^{k+d \max } \theta_{1 j} \ln Y_{t-j}+\sum_{i=1}^{k} \vartheta_{1 i} \ln X_{t-i}+\sum_{j=1}^{k+d \max } \pi_{1 j} \ln X_{t-j}+\lambda_{2 t}
\end{aligned}
$$

The null hypothesis that independent variable Xt does not cause dependent variable Yt is constructed as follows: $\mathrm{H} 0: \phi_{1}=\phi_{2}=\ldots=\phi_{\mathrm{i}}=0$. Similarly, in Equation (5), the null hypothesis that $Y_{t}$ does not cause Xt is formulated as follows: $H_{0}=\delta_{1}=$ $\delta_{2}=\ldots=0$

\section{Empirical Results}

Table 1 gives the ADF and PP unit root testing results of economic growth, physical capital, male and female human capital. All of the series are non-stationary (contain a unit root) in their levels but are stationary in their first differences. Thus, they are integrated of order one, I(1). 
Table 1: ADF and PP tests for unit root

\begin{tabular}{|c|c|c|c|c|}
\hline \multicolumn{5}{|c|}{$\mathrm{ADF}$} \\
\hline & \multicolumn{2}{|c|}{ Level } & \multicolumn{2}{|c|}{ First Difference } \\
\hline & $\tau \mu$ & $\tau \eta$ & $\tau \mu$ & $\tau \eta$ \\
\hline $\mathrm{Y}$ & $0.603[0]$ & $-1.798[1]$ & $-6.272[0]^{* * *}$ & $-6.380[0]^{* * *}$ \\
\hline PHY & $-1.930[0]$ & $-3.013[1]$ & $-6.219[0]^{* * *}$ & $-6.123[0]^{* * *}$ \\
\hline MHUM & $-1.779[0]$ & $-1.480[0]$ & $-5.930[0]^{* * *}$ & $-6.085[0]^{* * *}$ \\
\hline FHUM & $-2.018[0]$ & $-1.545[0]$ & $-6.134[0]^{* * *}$ & $-6.513[0]^{* * *}$ \\
\hline \multicolumn{5}{|l|}{$\mathrm{PP}$} \\
\hline & \multicolumn{2}{|c|}{ Level } & \multicolumn{2}{|c|}{ First Difference } \\
\hline & $\tau \mu$ & $\tau \eta$ & $\tau \mu$ & $\tau \eta$ \\
\hline $\mathrm{Y}$ & $0.645[3]$ & $-1.921[1]$ & $-6.274[2] * * *$ & $-6.379[3]^{* * *}$ \\
\hline PHY & $-1.987[2]$ & $-3.038[1]$ & $-6.456[6]^{* * *}$ & $-6.326[6]^{* * *}$ \\
\hline MHUM & $-1.779[0]$ & $-1.547[2]$ & $-5.918[2]^{* * *}$ & $-6.085[0]^{* * *}$ \\
\hline FHUM & $-2.051[1]$ & $-1.575[3]$ & $-6.147[3] * * *$ & $-6.513[1] * * *$ \\
\hline
\end{tabular}

Note: All variables are expressed in logarithmic form. $\tau \mu$ represents the model with a drift and without trend; $\tau \eta$ is the most general model with a drift and trend. The optimal lag lengths used in the ADF test are indicated within brackets and determined by the AIC. When using PP test, the values in brackets represent Newey-West Bandwidth (as determined by Bartlett Kernel). $(*),(* *)$ and $(* * *)$ indicate that the corresponding coefficient is significant at $10 \%, 5 \%$, and $1 \%$ levels, respectively.

Following the results of unit root and stability tests, the long-run relationship between the variables can be investigated by using the bounds test to cointegration within the ARDL modeling approach developed by Pesaran et al. (2001). In this context, the lag length of the estimation is determined. Because annual data are used, the maximum number of lags in the ARDL was set equal to 4 . The lag length that provides the smallest critical value is determined as the lag length of the model by using several lag selection criteria such as AIC, SC, HQ, FPE, and LR. Pesaran et al. (2001) provide the set of asymptotic critical values. However, according to Narayan (2005), the existing critical values reported in Pesaran et al. (2001) cannot be used for small sample sizes because they are based on large sample sizes for 500 and 1000 observations. Therefore, Narayan (2005) provides a set of critical values for sample sizes ranging from 30 to 80 observations. The calculated F-statistics for Equation (1) is found as 6.499, which is above the critical values of both Pesaran et al. (2001) and Narayan (2005). In this context, the null of no cointegration can be rejected, implying that there exists a long-run relationship or cointegration between economic growth, physical capital, male and female human capital. 
Table 2: Results of bounds test for cointegration

\begin{tabular}{|c|c|c|c|c|c|}
\hline \multicolumn{2}{|c|}{ Model } & \multicolumn{3}{c|}{ F-statistic } \\
\hline \multicolumn{2}{|c|}{ PesHY, MHUM, FHUM $)$} & \multicolumn{3}{c|}{ Narayan (2005) } \\
\hline \multicolumn{3}{|c|}{ Pesaran et.al (2001) } & \multicolumn{3}{c|}{$\mathrm{T}=45$} \\
\hline Critical Value & Lower Bound & Upper Bound & Critical Value & Lower Bound & Upper Bound \\
\hline $1 \%$ & 4.29 & 5.61 & $1 \%$ & 4.98 & 6.42 \\
\hline $5 \%$ & 3.23 & 4.35 & $5 \%$ & 3.53 & 4.73 \\
\hline $10 \%$ & 2.72 & 3.77 & $10 \%$ & 2.89 & 3.98 \\
\hline
\end{tabular}

Notes: $(*),(* *)$ and $(* * *)$ indicate that the corresponding coefficient is significant at $10 \%, 5 \%$, and $1 \%$ levels, respectively. Critical values are citied from Narayan (2005:1988) and Pesaran et.al (2001:300) (Table Case III: Unrestricted intercept no trend)

After establishing the cointegration relationship for Equation (1), the next step is to estimate the long-run coefficients of the equation by using the ARDL specification. Owing to the ARDL specification, it is assumed that the errors are serially uncorrelated and the maximum lag is selected as 4 according to the lag length criteria, where no autocorrelation is found in Equation (1). The estimated long-run coefficients of ARDL $(4,0,5,4)$ model are given in Table 3.

Table 3: Estimated long-run coefficients using ARDL approach

\begin{tabular}{|l|c|}
\hline Regressors & ARDL $(4,0,5,4)$ \\
\hline Constant & $3.43510[84.821]^{* * *}$ \\
\hline PHY & $0.171[4.936]^{* * *}$ \\
\hline MHUM & $3.625[7.836]^{* * *}$ \\
\hline FHUM & $-2.128[-4.509]^{* * *}$ \\
\hline
\end{tabular}

Note: $\mathrm{t}$-values are given in parentheses. $(*),(* *)$ and $(* * *)$ indicate that the corresponding coefficient is significant at $10 \%, 5 \%$, and $1 \%$ levels, respectively.

The long-run coefficients show that all regressors in the economic growth equation exhibit the positive sign and are statistically significant at the $1 \%$. While the long-run coefficient of physical capital and male human capital is positive, the longrun coefficient of female human capital is found negative and statistically significant. These findings support the effect of male human capital on Turkish economy. A $1 \%$ increase in male human capital increases the economic growth by 3\%. The longrun results support the human-capital-based endogenous growth theory for men in Turkey, and the physical capital also affects the economic growth. These results also suggest that highly educated women are not well utilized in the labor markets and thus in the economy in Turkey.

The error correction model was also estimated within the ARDL framework. The results of the short-run dynamic coefficients related to the long-run relationships estimated by Equation (1) are reported in Table 4. These estimates provide further direct 
evidence on the complicated dynamics that seem to exist between economic growth and its determinants.

Table 4: Error correction model

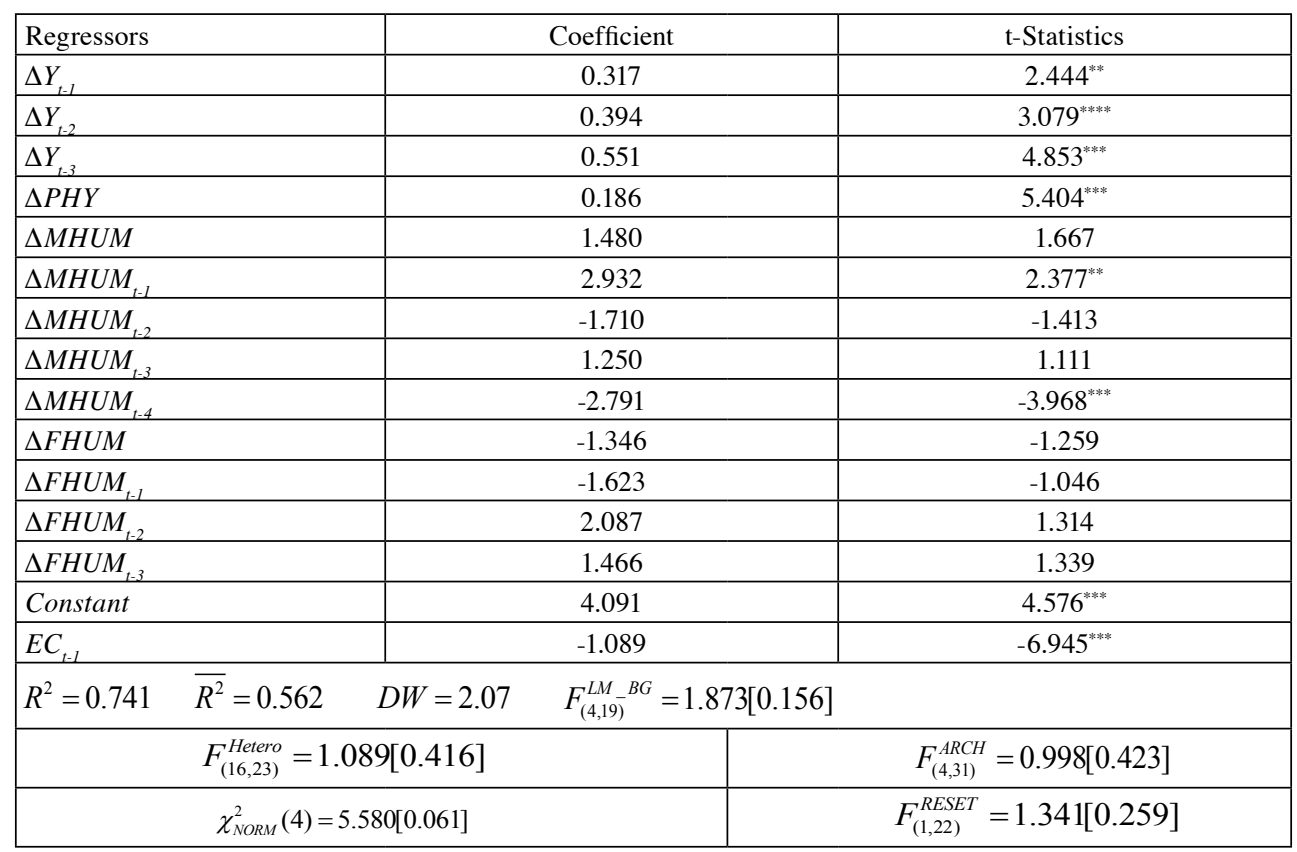

Note: t-values are given in parenthesis. $(*),(* *)$ and $(* * *)$ indicate that the corresponding coefficient is significant at $10 \%, 5 \%$, and $1 \%$ levels, respectively.

The short-run results are not much different from the long-run estimates. The sign of the short-run coefficients for physical capital is positive and statistically significant but the same for male and female human capital is non-significant and positively and negatively related to economic growth, respectively. The results for the 19712015 period show that the error correction term, $\mathrm{ECT}_{\mathrm{t}-1}$, is negative and statistically significant, indicating that the feedback mechanism is effective in Turkey. In other words, the convergence to long-run equilibrium after a shock to capital formations is relatively high in Turkey's economic growth. The value of 1 suggests that a deviation from the long-run equilibrium level of economic growth is corrected in one year. In other words, $100 \%$ of the adjustment takes place within the period. In addition, the significant error correction term further confirms the existence of a stable long-run relationship.

The model passes the specification tests, such as the tests of no residual autocorrelation, no residual ARCH effects, residual normality, and no residual heteroscedasticity and the RESET test for functional form misspecification. The cumulative sum 
(CUSUM) and the cumulative sum of squares (CUSUMQ) tests were employed to determine whether the parameters in the models are stable. The results of CUSUM and CUSUM-Q tests are shown in Figure 1. The lines show the boundaries of 5\% significance levels. It can be seen in the figures that the parameters are stable; the sum of the squared residuals lies inside the critical bounds of 5\% significance.

Figure 1: CUSUM and CUSUM Q test results for coefficient stability

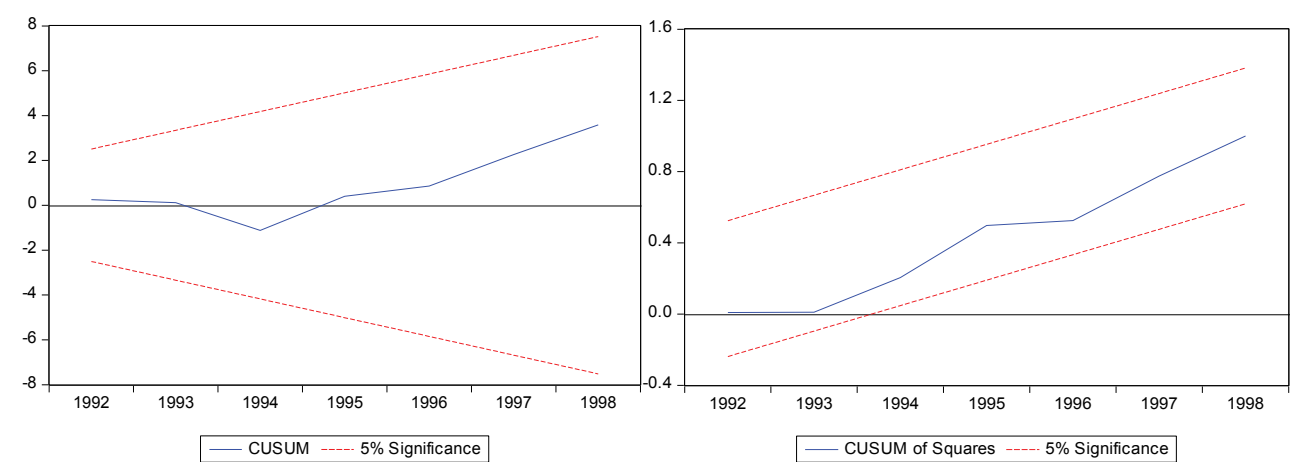

Toda and Yamamoto's procedure (1995), which employs a modified Wald test does not require pre-testing for the cointegrating properties of the system and is valid regardless of whether a series is $I(0), I(1)$ or $I(2)$, non-cointegrated or cointegrated in an arbitrary order 'as long as the order of integration of the process does not exceed the true lag length of the model' (Toda and Yamamoto, 1995:225). Therefore, the results of Toda-Yamamoto's version (1995) of the Granger causality test are presented in Table 5.

Table 5: The results of Toda-Yamamoto's causality test

\begin{tabular}{|c|c|c|c|}
\hline Null Hypothesis & $\chi^{2}$-statistic & Probability value & Decision \\
\hline MHUM does not cause Y & 11.147 & $0.000^{* * *}$ & Bidirectional Causality \\
HM $\leftrightarrow$ Y \\
\hline Y does not cause MHUM & 4.560 & $0.032^{* *}$ & Bidirectional Causality \\
MHUM does not cause PHY & 6.272 & $0.012^{* *}$ & HM $\leftrightarrow$ PHY \\
\hline PHY does not cause MHUM & 3.691 & $0.054^{*}$ & \\
\hline
\end{tabular}

Notes: $(*),(* *)$, and $(* * *)$ indicate that the corresponding coefficient is significant at $10 \%, 5 \%$, and $1 \%$ levels, respectively. VAR is estimated by $[\mathrm{k}+\mathrm{dmax}]=2$ for the model, optimal lag length $\mathrm{k}=1$ is selected by lag length criteria, $\operatorname{dmax}=1$.

According to Toda-Yamamoto's causality test results, it can be concluded that the causal relationship between male human capital and economic growth and male human capital and physical capital is bi-directional. However, there is no evidence of causality is found running from the female human capital to other variables. This result suggests that women are not well utilized in the Turkish economy. The results 
imply the significant effect of the male human capital on the Turkish economy. Male human capital has been the central variable, being caused by both economic growth and physical capital for the period of 1971-2015.

\section{Conclusion}

This study has empirically investigated the relationship between economic growth, physical capital, and male and female human capital in Turkey using the yearly data from 1971 to 2015. Generally, the education and health indicators are used as a proxy for human capital in most of the studies. In this study, by using the arithmetic average of health and education indicators as a proxy of human capital formation, an attempt was made to trace out the relationship between the human capital and economic growth under the scope of gender inequality. The empirical results show that there exists a long run co-integration among physical capital, female human capital, male human capital, and economic growth. The estimates of ARDL reveal that physical capital and male human capital are significantly and positively related to economic growth in both short-run and long-run. The results support the human-capital-based endogenous growth theory for men in Turkey. However, the contribution of female human capital to economic growth was found to be negative both in the short-run and long-run. The results concord well with those reported by Barro and Lee (1994), Barro (2001) and Cooray et al. (2014). Furthermore, the causality test results support the findings of ARDL estimates. The results imply a significant effect of the male human capital on the Turkish economy. Male human capital has been the central variable, being caused by both economic growth and physical capital for the period of 1971-2015. Through bi-directional causality, a feedback effect was found between economic growth - male human capital and physical capital - male human capital. The effective use of physical capital and contribution to economic growth is possible with male human capital. However, there is no evidence of causality that runs from the female human capital to other variables.

These results suggest that women are not well utilized in the Turkish economy and Turkey suffers from untapped potential of women. As argued by Barro (2001), the reason for female secondary (and above) education having a negative effect on growth is possibly due to gender differentials in education that restrict the optimal employment of educated females in the labor market. Gender-based preferences can lead to unequal resource allocations to men and women in the same economy. Women in Turkey appear to be concentrated in low-productivity jobs. Men are more employed in the industrial sectors $(21.5 \%)$ than women $(15 \%)$, which contributes to the country's economic growth. As argued by Coorey et al. (2014) the manufacturing sector of textile and clothing industry show a low skilled labor-intensive nature and employ a large proportion of females, as in Turkey. In addition to this $29 \%$ of Turkish 
women employed in the agricultural sector are mostly unpaid family workers and 55\% of women employed in the service sector. This includes, education (18\%) and health sectors (17\%), where women employed in jobs defined as women's work in these sectors. Due to the effect of gender-based occupational segregation, both highly educated and uneducated women are referred to female-dominated occupations and this can reduce women's productivity by limiting their ability to gather and share information and potentially access markets. Moreover, the ongoing structural transformation of the Turkish economy and the migration from rural areas to cities cause a withdrawal of women from the labor force or engagement in informal sectors. To sum up, under the scope of socio-cultural and economic constraints, women in Turkey face many difficulties that prevent them from participating in the economy. As stated in the World Bank Report (2009), countries cannot compete globally if they do not use the full potential of all their citizens. Turkey can be more benefited by a greater involvement of women in the workforce. Women's economic participation is necessary to improve education and health outcomes for the future generations and making ways for economic growth and poverty reduction. For these reasons, the continuous investment in the education of girls and women is also vital for the labor force participation of women in Turkey. The access to higher education increases the labor force participation of women and raises the reservation wage. However, the education needs to be matched by creating jobs in the economy. Improving the quality of education is critical to achieve high employment and offer opportunities for better jobs for women. Moreover, women could be encouraged to work by having access to affordable childcare and providing child, sick and elderly care services in Turkey (Karaalp-Orhan, 2017). The efforts to increase human capital accumulation, to enhance the quality of education, and to decrease gender inequalities are crucial for Turkey's long-run economic growth.

\section{REFERENCES}

Barro, R.J. (1991). Economic growth in a cross-section of countries. The Quarterly Journal of Economics. 106(2), 407-433. DOI: 10.2307/2937943

Barro, R.J. (2001). Human capital and growth. American Economic Review. 91(2), 12-17. DOI: 10.1257/ aer.91.2.12.

Barro, R.J. \& Lee J.W. (1993). International comparisons of educational attainment. Journal of Monetary Economics, 32(3), 363-394. DOI: 10.1016/0304-3932(93)90023-9.

Barro, R.J. \& Lee, J.W. (1994). Sources of economic growth. Carnegie-Rochester Conference Series on Public Policy. 40, 1-46. DOI: 10.1016/0167-2231(94)90002-7.

Barro, R.J. \& Lee, J.W. (1996). International measures of schooling years and schooling quality. American Economic Review, 86(2), 218-223.

Barro, Robert J. \& Lee, J.W. (2013). A new data set of educational attainment in the world, 1950-2010, Journal of Development Economics.104,184-198. DOI: 10.1016/j.jdeveco.2012.10.001.

Becker, G.S. (1964). Human Capital. Princeton, N.J. Princeton University Press.

Becker, G.S. (2007). Health as human capital: synthesis and extensions. Oxford Economic Papers. 59, 379-410. DOI:10.1093/oep/gpm020. 
Chow, G. (1993). Capital formation and economic growth in china. Quarterly Journal of Economics. 108(3), 809-842. DOI: https://doi.org/10.2307/2118409.

Clark, J. A. \& Mirza, S. (2006). A Comparison of some common methods of detecting ganger noncausality. Journal of Statistical Computation and Simulation. 76(3), 207-231. DOI: https://doi. org/10.1080/10629360500107741

Dae-Bong, K. (2009). Human capital and its measurement. The 3rd OECD World Forum on "Statistics, Knowledge and Policy" Charting Progress, Building Visions, Improving Life Busan. Korea - 27-30 October 2009 Retrived 01.03.2018 from http://www.oecd.org/site/progresskorea/44109779.pdf.

Dickey, D. A. \& Fuller W.A. (1979). Distribution of the estimators for autoregressive time series with a unit root, Journal of the American Statistical Association. 74(366), 427-431. DOI: $10.2307 / 2286348$.

Engle, R.F. \& Granger, C.W.J. (1987). Co-integration and error correction: representation, estimation and testing. Econometrica. 55(2), 251-276. DOI: http://dx.doi.org/10.2307/1913236.

Chuang, Y. (2000). Human capital, exports, and economic growth: a causality analysis for taiwan, 19521995, Review of International Economics. 8(4), 712-720. DOI: https://doi.org/10.1111/14679396.00252.

Cooray, A., Mallick, S. \& Nabamita, D. (2014). Gender-specific human capital, openness and growth: exploring the linkages for southasia. Review of Development Economics, 18(1), pp.107-122. DOI: https://doi.org/10.1111/rode.12072

Granger, C.W.J. (1969). Investigating causal relations by econometric models and cross spectral models. Econometrica. 37(3), 424-438. DOI: 10.2307/1912791.

Hu, Z.L. \& Khan, M.S. (1997). Why is china growing so fast?. IMF Staff Papers. 44(1), 103-131.

Johansen, S. \& Juselius, K. (1990). Maximum likelihood estimation and inference on cointegration with applications to the demand for money. Oxford Bulletin of Economics and Statistics. 52(2), 169-210. DOI: https://doi.org/10.1111/j.1468-0084.1990.mp52002003.x

Jung, H. \& Thorbecke, E. (2003). The impact of public education expenditure on human capital, growth, and poverty in tanzania and zambia: a general equilibrium approach. Journal of Policy Modeling. 25(8), 701-725. DOI: https://doi.org/10.1016/S0161-8938(03)00060-7.

Karaalp-Orhan, H.S. (2017a). Human capital and economic growth: bounds and causality analysis for turkey. Research Journal of Politics, Economics and Management. 5(1), 21-32.

Karaalp-Orhan, H.S. (2017b). What are the trends in women's labour force participation in turkey? European Journal of Sustainable Development. 6(3), 303-312. DOI: 10.14207/ejsd.2017. v6n3p303.

Kaur, N.G. \& Letic, J. (2012). Female education and economic growth: theoretical overview and two country cases, Unpublished BSc dissertation, School of Business, Economics and Law, University of Gothenburg.

Khan, S.R., Shaw, W.D. \& Hussain, F. (1991). Causality between literacy and labor productivity in pakistan, Economics of Education Review, 10(3), 245-251. DOI: https://doi.org/10.1016/02727757(91)90047-S.

Khan, K.M. (2016). Contribution of female human capital in economic growth: an empirical analysis of pakistan (1972-2012). Quality \& Quantity. 50(2), 709-728. DOI: https://doi.org/10.1007/ s11135-015-0172-6.

Knowles, S. \& Owen, P. D. (1995). Health capital and cross-country variation in income per capita in the Mankiw-Romer-Weil model. Economics Letters. 48(1), 99-106. DOI: https://doi. org/10.1016/0165-1765(94)00577-O

Knowles, S., Lorgelly, P. K., Owen, P. D. (2002). Are educational gender gaps a brake on economic development? some cross-country empirical evidence. Oxford Economic Papers. 54, 118-149. DOI: 10.1093/oep/54.1.118. 
Krugman, P. (1994). The myth of asia's miracle. Foreign Affairs. 73(6), 62-78. DOI: http://dx.doi. org/10.2307/20046929

Lee, J. (2005). Human capital and productivity for korea's sustained economic growth. Journal of Asian Economics. 6(4), 663-687. DOI: https://doi.org/10.1016/j.asieco.2005.06.009

Lucas, R. (1988). On the mechanisms of economic development. Journal of Monetary Economics. 22(1), 3-42. DOI: https://doi.org/10.1016/0304-3932(88)90168-7

Morrison, A., Raju, D. \& Sinha, N., (2007). Gender equality, poverty, and economic growth. Policy Research Working Paper No. 4349. Washington, DC: World Bank

Önder K and Önder E. (2012). The role of the female education in economic growth: a case for turkey, Gümüşhane Üniversitesi Sosyal Bilimler Elektronik Dergisi. 5,59-176.

Öztunç H., Oo, Z.C. \& Serin, Z.H. (2015). Effects of female education on economic growth: a cross country empirical study. Educational Sciences: Theory and Practice. 15(2), 349-37. DOI: 10.12738/estp.2015.2.2351

Pesaran, M.H., Yongcheol, S. \& Smith R.S. (2001). Bounds testing approaches to the analysis of level relationships. Journal of Applied Econometrics. 16(3), 289-326. DOI: https://doi.org/10.1002/ jae.616.

Phillips, P.C.B. \& Perron, P. (1988). Testing for a unit root in time series regression. Biometrika Trust. 75(2), 335-346. DOI: 10.2307/2336182

Pitarakis, J.Y. \& Tridimas G.G. (2003). Joint dynamics of legal and economic integration in the european union. European Journal of Law and Economics. 16(3), 357-368. DOI: https://doi. org/10.1023/A:1025366909016.

Romer, P.M. (1990). Are non-convexities important for understanding growth. The American Economic Growth. 80(2), 97-103.

Sehravat, M. \& Giri, A.K. (2017). Does female human capital contribute to economic growth in india?: an empirical investigation. International Journal of Social Economics. 44(11), 1506-1521. DOI: https://doi.org/10.1108/IJSE-10-2015-0272.

Schultz, T.W. (1961). Investment in human capital. The American Economic Review. 51(1), 1-17.

Schultz, T.P. (2003). Human capital, schooling and health returns. Working Papers 853, Economic Growth Center, Yale University.

Sims, C.A., Stock, J.H. \& Watson, M.W. (1990). Inference in linear time series models with some unit roots, Econometrica. 58(1), 113-144. DOI:10.2307/2938337.

Solow, R. M. (1956). A Contribution to the theory of economic growth. Quarterly Journal of Economics. 70(1), 65-94. DOI: 10.2307/1884513

Tansel, A. \& Güngör, N. (2013). Gender effects of education on economic development in turkey, Journal of Economic Studies. 40(6), 794-821. DOI: https://doi.org/10.1108/JES-10-2012-0140.

Thirlwall, A.P. (2006). Growth and development - with special reference to developing economies (8th ed.). Hampshire: Palgrave MacMillian.

Toda, H.Y. \& Yamamoto, T. (1995). Statistical inference in vector autoregressions with possibly integrated process. Journal of Econometrics. 66(1-2), 225-250. DOI: https://doi.org/10.1016/03044076(94)01616-8.

TurkStat (2018), Labor force Statistics, Retrived 01.03.2018 from http://www.tuik.gov.tr/PreTablo. do?alt_id=1007.

Wang, Y. \& Yao, Y. (2003). Sources of china's economic growth 1952-1999: incorporating human capital accumulation. China Economic Review. 14(1), 32-52. DOI: https://doi.org/10.1016/ S1043-951X(02)00084-6.

Wolde-Rufael, Y. (2007). Another look at the relationship between telecommunications investment and economic activity in the United States, International Economic Journal, 21(2): 199-205. DOI: $10.1080 / 10168730701345372$

World Bank (2009), Turkey's greatest untapped potential? Women. Retrived 01.03.2018 from http://www. worldbank.org/en/news/press-release/2009/09/15/turkeys-greatest-untapped-potential-women. 